\title{
On the problem of renovation of socio-cultural constants that have constructive potential for development of regional communities
}

\author{
Valentin Babintsev, Galina Gaidukova*, and Zhanna Shapova \\ Belgorod State National Research University, 308015 Belgorod, Russia
}

\begin{abstract}
In the article, the authors, on the basis of a socio-technological approach, design step-by-step procedures for the renovation of sociocultural constants that have a constructive potential for the reproduction and development of regional communities. It is noted that the sociotechnological solution to the problem of the renovation of socio-cultural constants in the region presupposes the construction of this paper according to the model of an algorithm, which is the order of performing an exact sequence of actions that are clear to the executor, ensuring the achievement of the result. Proceeding from the nonlinearity of the constant renewal process, the authors substantiate the need to use a flexible algorithm, that is, an algorithm with branching, which assumes that the transition to subsequent procedures (actions) is carried out depending on the results of checking the performance of the previous procedure. In such an algorithm, reflection of completed procedures and, on the basis of it, the choice of possible further actions, which is quite adequate to the requirements of the socio-technological approach, acquires particular importance. In the algorithm for the renovation of sociocultural constants, the authors distinguish the following sequential procedures: initiation of the renovation of a constant or a system of constants; expert assessment of the validity of the choice; establishing the degree of complementarity of the constants to the dominant attitudes and orientations of the mass consciousness; establishing a normative interpretation of the content of a constant; decomposition of a constant in the form of a system of ideas, images, symbols, everyday ideas; the transformation of a constant into a permanent element of regional public discourse; formation of the "asset" constant; building a constant infrastructure. The basis for reflection at all stages of the constructed algorithm shall be the results of diagnostics (self-diagnostics).
\end{abstract}

\section{Introduction}

In a globalizing unstable society (often defined by researchers as a "postmodern society" [1-4]), where the relativity and conventionality of social realities are postulated, there is an urgent need for firmly established sociocultural guidelines (constants) recognized by the majority of citizens. These can be value patterns, social norms, sign systems, and behavioral

\footnotetext{
${ }^{*}$ Corresponding author: g_gaidukova@,bsu.edu.ru
} 
models. In some cases, they can become a reliable basis for social reproduction and development of society, including at the level of local communities (regions, cities and municipalities). These constants are immanently contained in the historical development of territories, and can potentially be revived and used considering the specifics of the current situation. This process is the essence of renovation of socio-cultural constants, since it simultaneously characterizes the restoration (revival) of the possibilities inherent in them and the denial of what is not adequate to the humanitarian prospects of development. However, even if there is political will to solve the problem of renovation and social consensus about its importance, any actions aimed at updating socio-cultural constants in the new conditions require scientific substantiation.

\section{Methods}

The purpose of the article is a conceptual substantiation of a step-by-step algorithm for the renovation of sociocultural constants, which can be used by state and municipal authorities, civil society institutions for reproduction and development of Russian regions.

The article is based on the theory of social risks, according to which risk is increasingly becoming a leveling norm of everyday existence in an unstable social environment, as well as the theory of social anomie (a state of value instability of society).

The study is based on the law of techno-humanitarian balance formulated in the field of cultural anthropology, according to which the higher the power of production and combat technologies, the more advanced means of cultural and psychological regulation are necessary to preserve society.

In the process of study, general and particular methods of scientific research, comparative, systemic, formal-logical analysis, bibliographic research, and analysis of documentary sources were also used.

Within the framework of this article, renovation is understood as the actualization of a socio-cultural phenomenon in public consciousness and its subsequent transformation into a factor influencing the behavior of large social groups. The limits of this influence are determined by the scale of the location in which the renovation process is initiated. In this article, the problem is considered in relation to the region, which is understood as any constituent entity of the Russian Federation, therefore, we shall talk about the support of most of the regional community, including both the regional elite and the bulk of the population $[5]$.

The renovation of socio-cultural constants can be considered as a kind of regional project only if it is rationalized and goal-oriented. Wherein, although the rationalization of the process does not guarantee its success, it creates an opportunity for building it in the form of a social technology, which is a system of algorithmic actions. According to a number of researchers, it is the socio-technological approach to the management of social processes that is most in demand in modern society. L.Ya. Dyatchenko once wrote: "A well-thought-out technology is required to create conditions for society to develop without authoritarian pressure, infringement of the rights and freedoms of an individual and social groups. To solve this national problem, it is necessary to develop and implement various regional and local programs, i.e. social technologies at the meso-level, the design of which can be carried out by rather small groups uniting scientists and specialists of various profiles" [6, p. 4]. Today, in the context of the hybridization of social reality associated with its saturation with technology and technology, the socio-technological approach seems to be the most promising paradigm for its design and change, since it makes it possible to implement solutions to these problems in the form of a two-sided scientifically grounded research-solution process [7].

With all the variety of definitions of social technology, they most often emphasize their algorithmic nature. I.V. Burmykina, namely, writes: "Social technology is a specific method 
of activity, which has an algorithmic essence, to manage the social process in these conditions and in this social "field", a context based on the value-goal attitudes of the subjects of social action" [8 , p. 252]. The point of view of G.Kh. Valeeva and N.A. Shangareyev who assert: "Development and existence of society is based on the informational development algorithm -social technology" [9, p. 14]. Finally, O.A. Urzha defines social technologies as "proven algorithms of influence, which are procedures, operations, techniques suitable for a specific area of human activity: technologies for increasing labor productivity; technologies of political pre-election struggle; teaching technologies, and etc " [10, p. 94].

Therefore, the socio-technological solution to the problem of the renovation of sociocultural constants in the region presupposes the building of this work according to the model of an algorithm, which is an order of performing an exact sequence of actions that are clear to the executor, ensuring the achievement of the result. Any algorithm has the properties of discreteness, definiteness (determinism), effectiveness, mass character and efficiency.

However, it is necessary to take into account the fact that different types of algorithms are used in practice. Most often they are divided into linear, branching algorithms, and repetition algorithms. In the interpretation of I.V. Burmykina these are mechanical and flexible algorithms. The author writes: "If mechanical algorithms specify certain actions, designating them in a unique and reliable sequence, thereby providing an unambiguous required or desired result for the achievement of which algorithms have been developed; then the flexible ones set the program for solving the problem in several ways or methods leading to the probable achievement of the result, or such a sequence of actions in which the achievement of the final result, the program of actions is not unambiguously predetermined, just as the entire sequence of actions is not indicated, all the actions of the performer are not identified" [8, p. 250].

We believe that a flexible algorithm in this case is understood as an algorithm with branching, which assumes that the transition to subsequent procedures (actions) is carried out depending on the results of checking the execution of the previous procedure (Fig. 1).

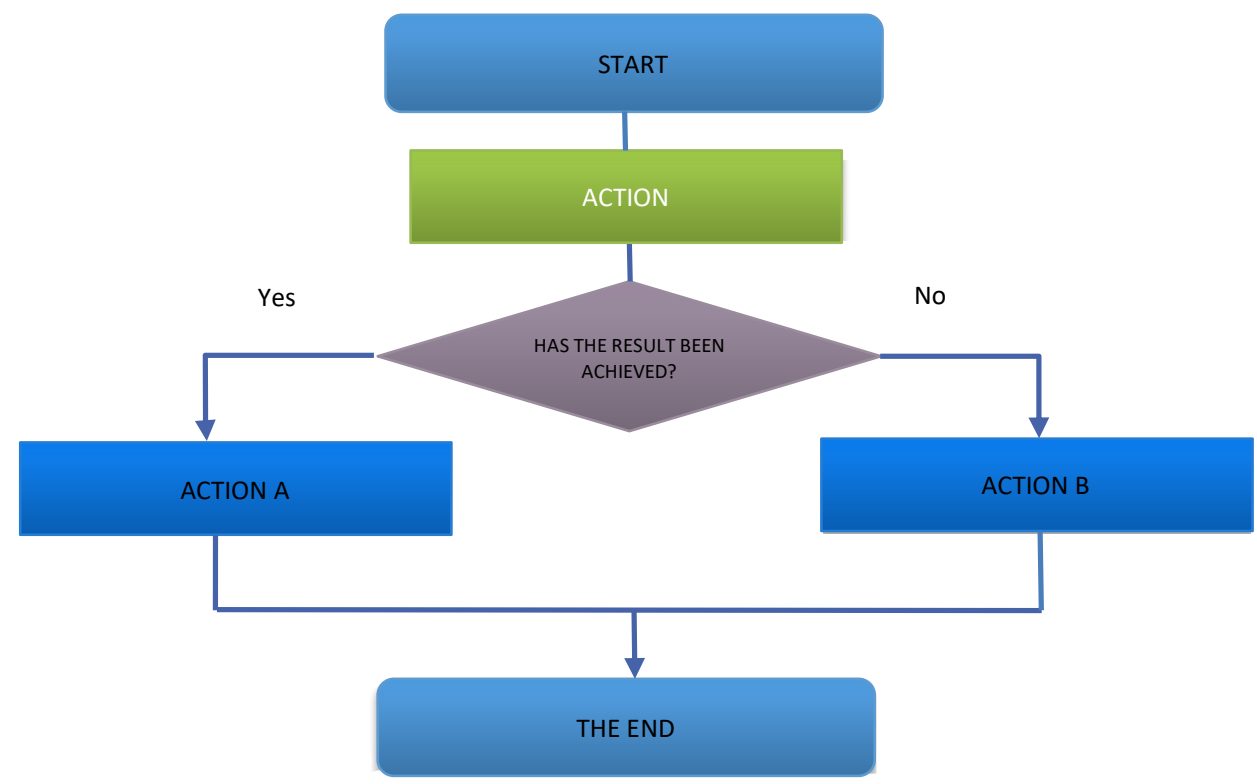

Fig.1. An example of a branching algorithm.

The feasibility of using this particular type of algorithm during the renovation of sociocultural constants is determined by the nonlinearity of this process, the transitions to the implementation of each procedure of which can be considered as bifurcation points that 
predetermine the possibility of various scenarios for the development of events. Their choice is carried out under the influence of a complex of factors (branching factors).

In this case, reflection of completed procedures and, on the basis of it, the choice of possible further actions, which is quite adequate to the requirements of the socio-technological approach, acquires particular importance. In this regard, the position of I.A. Kolesnikova who defines technology as "a logical sequence of operations reflected at the level of professional consciousness, reflecting an objective, most harmonized in relation to certain conditions, reproducible way to achieve a specific goal" (in this case, production) [11, p. 223].

The basis for reflection at all stages should be the results of diagnostics (self-diagnostics), which, according to O.A. Urzhi, is an algorithmized procedure for "permanent" removal" of the characteristics of the surveyed object, their indicators and factors under the influence of which these indicators change, the dynamics of these changes. The information received about the state of a social object is used to develop a decision on the impact on the factors that determine it, as well as its direction [10, p. 91].

\section{Results}

In the process of renovating sociocultural constants, we consider it possible to single out the following algorithm procedures:

1. Initiating the renovation of a constant or system of constants. Although the process of renovating the constants can be initiated by one of the main actors in the regional social space (government bodies, any of the institutions of civil society, associations of entrepreneurs), it requires the agreement of its "players". If a consensus is reached, the transition to the second procedure is carried out; if it is not achieved, the idea is either abandoned, or revise the set of potential constants.

The branching factor in this case is the presence/absence of an agreement on the initiation of the renovation of a constant between the leading players of the regional space, the achievement of which in some cases may be associated with difficulties due to the mismatch of group interests, different interpretations of proposals regarding the composition of the constants. The institutionalization of the agreement, as the experience of the renovation of the constant of solidarity in the Belgorod region shows, can be implemented in the form of an agreement signed by representatives of state, municipal and public structures.

In this case, it is advisable to diagnose the results of the procedure in the form of a brainstorming session with the participation of the initiators of the idea.

2. Expert assessment of the validity of the choice. The validity of the choice should be verified by professionals representing the regional expert community. This is a small group of people who have the ability and professional competence, are socially active in the field of mental work and use intelligence as a resource, both for ensuring success in life and for solving social problems. They have a specific way of mastering social reality, which is based on its comprehension in the form of conceptual and logical constructions and the use of the knowledge gained for the development and implementation of scientifically grounded concepts.

In case of a positive opinion of the experts, the transition to the third procedure is carried out; if it is negative, then either a refusal to implement the project follows, or a revision of the constants, or a re-examination is appointed.

The branching factor in this case is the content of the expert opinion. Wherein, it is important to consider that mistakes in the selection of experts are quite real. Due to this circumstance, diagnostics should be reduced to cross-sectional (involving several groups) peer review with the involvement of external specialists.

3. Establishing the degree of complementarity of the constants to the dominant attitudes and orientations of the mass consciousness. Since the renovation of constants can be 
successful only if they are relevant to the dominant attitudes of mass consciousness, it is necessary to establish this by sociological methods. A positive result means the transition to the fourth procedure; negative - either to refuse to renovate, or to revise the list of constants.

The branching factor in this case is the content of the analytical report on the research results and the recommendations formulated on its basis. Obviously, it shall be borne in mind that the conclusions of the study may be erroneous, which is often associated with its insufficient representativeness. Therefore, diagnostics during the implementation of the procedure consists in conducting an expert assessment of the correctness of the study.

4. Establishment of the normative interpretation of the content of the constant. Since the constant being renovated must be unambiguously interpreted, it must be conceptually substantiated by specialists. Formation of such a concept is initially associated with difficulties of a substantive nature, since almost all socio-cultural phenomena receive different interpretations depending on the position of the subject interpreting them. To develop the concept, it is advisable to create a working group of qualified specialists.

In case of a positive result of their work, the transition to the next procedure is implemented; if it is impossible to do this, it is carried out replacement of the team of specialists. Moreover, the second option can be difficult due to the shortage of professionals or their refusal to work.

The branching factor in this case is the presence/absence of a concept.

Diagnostics can be carried out in the form of discussing the concept at a scientific and practical forum.

5. Decomposition of a constant in the form of a system of ideas, images, symbols, everyday ideas. Since any constant shall be multiplied considering the specifics of the objects of influence, this paper shall be carried out by experts in the field of public opinion. Completion of it involves the transition to the sixth procedure; incompleteness requires a change in the performers of work, which can cause difficulties due to the lack of a choice of qualified specialists.

The branching factor in this case is the assessment of the degree of assimilation of multiplied ideas by target groups. It is advisable to carry out diagnostics by the method of focus groups, in which the perception of the elements of a constant by representatives of the regional community is tested.

6. The transformation of a constant into a permanent element of regional public discourse. The renovated constants shall become the subject of discussion in the media, social networks, and at public events in their entirety or as separate elements. The solution of this problem leads to the transition to the seventh procedure of the algorithm; its lack of resolution (may be associated with an inadequate choice of channels, lack of motivation of their employees) presupposes a revision of the PR campaign strategy.

The branching factor within the framework of this procedure is the content of the monitoring results, which makes it possible to assess the dynamics of the mass base (the share of citizens who separate them) of the renovated constants.

The form of diagnostics is a longitudinal sociological study with a mandatory expert survey.

7. Formation of the "asset" constant. To turn into a "fact" of mass consciousness, any constant must have its carriers in the form of leaders of public opinion, who are a kind of inducing nucleus, a kind of "agents" of the constants. The region shall form a system for identifying them, attracting supporters of the constant, motivating them to participate in its presentation. Presence of such a system presupposes movement towards the implementation of the eighth procedure of the algorithm; absence (usually associated with mistakes in identifying leaders and their ineffective motivation) requires a revision of the applied technologies.

The branching factor in this case is the formation / lack of formation of the leader's "pool". 
Diagnostics in this case can be implemented in the form of a list of leaders and an analytical report with an assessment of their capabilities.

8. Building the infrastructure of a constant. The infrastructure of a constant is understood as a complex of material objects (venues, clubs, creative houses, and etc.), organizations and structures coordinating their activities, which "physically" provide support for the "life" of the constant, its constant habitual presence in the space of regional discourse. The main social institutions should take part in solving this problem, legitimizing this work in the form of plans, projects and programs. They are subject to regular peer review with the formulation of recommendations for adjustments. Based on this assessment, in the future, proposals should be made to change the algorithm in connection with the transformation of the social situation.

\section{Discussion}

The presented algorithm, like any social technology, is based on a rational attitude to social practices and is limited in this respect. Not all elements of social reality can be available for formalization and rationalization. There are whole classes of psychoemotional and mental structures that lie outside of conceptual thinking, and, nevertheless, significantly affect social processes. Namely, the fact that the founder of conservatism E. Burke, called prejudices, understanding by them irrational attitudes of consciousness and considering them very useful for society [12]. A rationalized social system, as a rule, does not recognize their importance, is in constant conflict with them, thereby creating additional sources of instability and tension. Essentially irrational "prejudices" (to use the term of E. Burke) are capable of deconstructing any algorithms.

In addition, within the framework of the algorithm under consideration, the problem of choosing objects for renovation acquires real significance, which is initially difficult due to objective and subjective reasons. To the first, in our opinion, it is advisable to include the following:

- the socio-cultural dynamics of the historical development of Russian society and the state, during which the value-semantic complexes dominating in the public consciousness and the corresponding sociocodes of behavior have often radically changed; at the same time, new sociocultural phenomena sometimes radically denied the traditional ones ("the baptism of Rus"; the transformations of Peter I; the revolution of 1917; cultural, civilizational and geopolitical "breakdown" of the 90s of the XX century). In the course of the "renovation choice" (with this concept we define the process of selection of socio-cultural constants carried out by the actors of regional development), due, first of all, to ideological preferences, its subjects are able to absolutize the spiritual realities of one of the historical periods, giving them normative significance and considering all the others as deviations;

- cultural and civilizational heterogeneity of Russia and its regions. Despite the fact that its core is the Russian, basically Orthodox Christian tradition, the representatives of various ethnic and confessional groups form differences in relation to values and norms of behavior that are preferable to be guided by when defining and implementing behavioral strategies. This natural diversity, however, complicates the choice of sociocultural constants;

- the internal inconsistency of Russian culture and mentality. Note that even in educational literature it is emphasized as a "common place" that in a Russian person opposite qualities are combined at the same time: greatness, pride and lack of dignity; kindness, selflessness and individualism, a tendency to violence; willpower, striving for freedom and humility; prowess, unbridled daring and humility; great diligence, a penchant for creativity and laziness; heightened personality consciousness, ambition and impersonal collectivism; following tradition and nihilism [13, p. 87]. Perhaps the origins of this contradiction are rooted in the dual nature of the initial social self-organization of the emerging Slavic-Russian 
ethnos, which, as A.G. Kuzmin showed, combined the traditions of the territorial Slavic and consanguineous Russian community themselves. Territorial and consanguineous communities formed completely opposite reference social roles. The first stimulated openness, dialogue with the external environment, and self-government. The second is isolation, internal subordination and paternalism. The roles not only did not coincide, but contradicted each other [14, p. 18]. This inconsistency often serves as the basis not only for discussions about the nature of value-normative foundations that are organic for the national tradition, but is capable of provoking serious social conflicts.

Subjective reasons complicating the selection process are associated with two significant circumstances.

First, there is a discrepancy between the social and group interests of representatives of a regional society, due, on the one hand, to their unequal status in socio-economic stratification and, especially, in the political system; on the other hand, the peculiarities of their group consciousness, one of the most typical of which is the tendency towards an irrational perception of reality, based largely on prejudices. Researchers note that one of the "discoveries of the 20th century was the following: "modern man and modern society are much less rational and much more archaic than positivists and liberal politicians argued" [4, p. 39]. Meanwhile, the renovation of sociocultural constants makes sense only as a consequence of free, rationally motivated choice and presupposes: discursiveness; certainty of concepts and terms; consistency; validity, requiring the establishment of logical connections between judgments; openness to criticism; reflexivity; admitting changes.

Secondly, the selection process significantly complicates the inclination of the actors of the regional (as well as the federal) socio-cultural space to mythologize the problems of spiritual realities. It is most clearly expressed in giving them a supra-institutional, mystical character. As a result, the constants chosen as patterns are endowed with an attribute of exclusivity, which should directly or indirectly confirm the exclusivity of their carriers. A typical example of the definition of such constants is the reasoning of the famous publicist $\mathrm{K}$. Dushenov, who quite adequately expresses the essence of the mythological approach. Referring to the papers of Metropolitan John (Snychev), he formulates them as "truths that have crystallized over the long centuries of our history and have especially clearly confirmed their innocence in the course of the great Russian drama of the 20th century. In short, they are as follows:

- "The Russian Idea" is an insatiable striving for holiness, righteousness and purity.

- "Russian democracy" is conciliarity.

- "Russian ideology" is Orthodoxy.

- "Russian order" is a statehood.

- The "Russian state" is Russia in all the diversity of its historical forms of existence.

- "The state-political and at the same time moral-religious ideal of Russia is Holy Russia".

- "Patriotism is the religious duty of every pious Christian".

- "The Russian Orthodox Church is the conciliar conscience of the people..." [15].

For all the attractiveness of these truths, their adequacy to socio-historical realities and due to this circumstance - the ability to be perceived by the mass consciousness as sociocultural guidelines in modern Russian society, especially if we consider its multicultural nature, remains problematic. As a result, "beautiful" declarations are devalued, turning into "uplifting deceptions" used to manipulate people. Their essence ultimately boils down to the concept "Russians are not a specific ethnos, but a mysterious supernational that has no ethnic content" [16, p. 15].

Mythologemes arising in connection with implementation of the practice of determining sociocultural constants by subjects of social management at the regional level are quite widespread due to a number of reasons: 
- a relatively (in relation to the federal center) low level of intellectual development of most of the administrative and managerial elite, which causes an uncritical perception of quasiscientific concepts of the historical and cultural process;

- the weakness of the expert community, which could potentially offer a theoretically grounded solution to the problem of renovating socio-cultural constants;

- the desire of some representatives of the establishment of a constituent entity of the Russian Federation to demonstrate their own ability to formulate original ideas, which supposedly refutes their "technocratic one-dimensionality";

- the activity on the regional "field" of a number of ideologues from federal centers, offering their own speculative ideas as recipes for spiritual revival.

\section{Conclusion}

In conclusion, we note that development of socio-cultural constants can proceed according to the reproduction scenario, which is a continuous recreation of stable socio-cultural landmarks that allow people to build constructive communication strategies that correlate (or at least openly do not contradict) the national cultural and historical tradition. However, the scenario of sociocultural destruction also seems quite probable, that is, the collapse of the system of value orientations, forms and norms of sociocultural organization and regulation of people's vital activity. Implementation of a destructive scenario can lead to a socio-cultural crisis, the possible consequences of which will be either a cultural and civilizational collapse, or the renovation of socio-cultural constants. The algorithm offered within the framework of the article can serve as a basis for the implementation of the second option. However, its necessary conditions are the development and testing of diagnostic tools for the perception of constants by the population of the region, as well as substantiation of the system of principles for determining those of them that have a constructive potential for the reproduction of regional communities.

The theoretical significance of the study lies in the possibility of conceptual substantiation of the process of renovation of socio-cultural constants that contribute to the reproduction and development of regional communities. The practical significance of the work lies in the possibility of using the designed socio-technological algorithm for the renovation of socio-cultural constants by state and municipal authorities, civil society institutions in the course of socio-psychological regulation of regional development.

\section{Acknowledgments}

The study was supported by a grant from the Russian Science Foundation No. 21-18-00150, https://rscf.ru/project/21-18-00150/.

\section{References}

1. T. Gumenyuk, M. Palchynska, P. Herchanivska, Y. Kozak, N. Kobyzhcha, Overcoming the modern socio-cultural crisis - From postmodern to post-postmodern: theoretical aspects. International Journal of Criminology and Sociology, 10 (8), 745-752 (2021). Access mode: 10.6000/1929-4409.2021.10.88

2. G. Kien, Postmodernism Trumps All: The World Without Facts, Qu alitative Inquiry, 27 (3-4), 374-380 (2021). Access mode: 10.1177/1077800420918892 
3. W. Raussert, T. Lantz, J. Michael, Modernism and postmodernisms, The Routledge Handbook to the Culture and Media of the Americas, 156-169 (2020). Access mode: 10.4324/9781351064705-14

4. S. A. Barkov, V. I. Zubkov, Monologi i dialogi o postmoderne i postmodernizme (2019)

5. V. P. Babintsev, G. N. Gaidukova, Z. A. Shapoval, Territorial communities consolidation route, Laplage in Journal, 7 (Extra-E), 549-555 (2021). Access mode: https://doi.org/10.24115/S2446-622020217Extra-E1234p.549-555

6. L. Ya. Dyatchenko, Social'nye tekhnologii v upravlenii obshchestvennymi processami (1993)

7. O. N. Yanickij, Modernizaciya gumanitarnogo znaniya: praktika, metod, teoriya, Sociologicheskij zhurnal, 23 (4), 69-88 (2017). Access mode: 10.19181/socjour.2017.23.4.5529

8. I. V. Burmykina, Upravlenie formirovaniem i razvitiem social'no-tekhnologicheskoj kul'tury sovremennogo menedzhera: monografiya (2009)

9. G. H. Valeev, N. A. Shangareev, Regulyativno-upravlencheskaya sushchnost' social'noj tekhnologii, Vestnik Orenburgskogo gosudarstvennogo universiteta, 1, 14-18 (2009)

10. O. A. Urzha, Social'naya inzheneriya kak metodologiya upravlencheskoj deyatel'nosti, Sociologicheskie issledovaniya, 10, 88-96 (2017). Access mode: 10.17922/2071-36652015-14-5-180-191

11. I. A. Kolesnikova, Pedagogicheskaya real'nost': opyt mezhparadigmal'noj refleksii. Kurs lekcij po filosofii pedagogiki (2001)

12. E. Byork, Razmyshleniya o revolyucii vo Francii i zasedaniyah nekotoryh obshchestv $v$ Londone, otnosyashchihsya k etomu sobytiyu (1993)

13. V. A. V'yunov, Russkij kul'turnyj arhetip: stranovedenie Rossii (2011)

14. A. G. Kuz'min, Istoki russkogo nacional'nogo haraktera, Vestnik Moskovskogo universiteta, 5, 13-22 (1993)

15. K. Dushenov, Odin v pole voin. Sila Bozhiya -v nemoshchi chelovecheskoj (2020). Access mode: https://rusprav.tv/i-odin-v-pole-voin-106155

16. S. M. Sergeev, Russkaya naciya ili Rasskaz ob istorii ee otsutstviya (2017) 